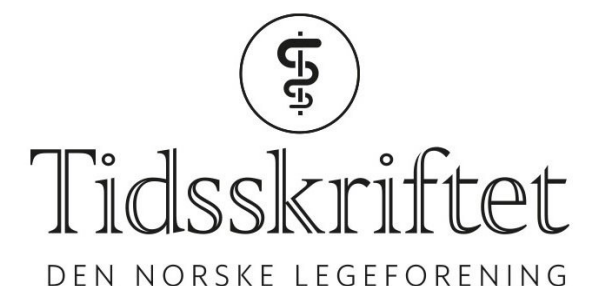

DEN NORSKE LEGEFORENING

\title{
Reell samhandling forebygger reinnleggelse
}

LEDER

\section{TORGEIR BRUUN WYLLER}

E-post: t.b.wyller@medisin.uio.no

Torgeir Bruun Wyller er professor i geriatri ved Universitetet i Oslo og overlege ved Geriatrisk avdeling ved Oslo universitetssykehus.

Forfatteren har fylt ut ICMJE-skjemaet og oppgir ingen interessekonflikter.

Vi kjenner til gode tiltak mot reinnleggelser, men har ikke tatt dem i bruk i særlig grad.

Årsaker til reinnleggelse i sykehus faller naturlig i tre hovedgrupper, eller eventuelt kombinasjoner av disse.

For det første kan pasienten bli reinnlagt på grunn av ny akutt sykdom eller akutt forverrelse av kronisk sykdom. Alvorlig hjertesvikt og alvorlig kols er eksempler på vanlige sykdommer der det tross god behandling lett kan inntreffe uforutsigbar klinisk forverring, og der en ny omgang med behandling i sykehus kan gi gevinst med hensyn til symptomer og prognose. I slike tilfeller er reinnleggelser nyttige, og fors $ø \mathrm{k}$ på å redusere dem vil kunne føre til redusert behandlingskvalitet.

For det andre kan pasienten bli reinnlagt fordi tilstanden ikke ble godt nok håndtert ved det første sykehusoppholdet. Ida Christine Lorentzen og medarbeideres interessante gjennomgang av 50 reinnleggelser ved Universitetssykehuset Nord-Norge retter søkelyset mot denne typen årsaker (1). Forfatterne påviser flere viktige forhold, f.eks. at utskrivningsdiagnosen etter reinnleggelsen ofte var knyttet til et annet organsystem enn diagnosen fra indeksoppholdet. Det illustrerer en velkjent fare, særlig i høyspesialiserte avdelinger i store sykehus: Man begrenser behandlingen til «sitt organ» og overser viktige komorbide tilstander. Pasienter med velavgrensede sykdommer behandles nå ofte poliklinisk eller som dagpasienter. De som trenger å ligge i en sykehusseng i flere døgn, er i økende grad preget av multisykelighet, og leger som skal ha behandlingsansvar for en slik pasientgruppe, bør ha tilstrekkelig breddekompetanse til at betydningsfull komorbiditet ikke forsømmes. Suboptimal informasjonsoverføring er også et uttrykk for kvalitetssvikt og er, slik Lorentzen og medarbeidere viser, vanlig (1).

Suboptimal informasjonsoverføring er også et uttrykk for kvalitetssvikt

For det tredje kan pasienter bli reinnlagt fordi de får et utilstrekkelig helsetilbud etter utskrivningen. «Lengst mulig i eget hjem» var lenge et slagord i pasientenes interesse. Nå brukes det mot pasienter som kunne fått en mer stabil helsetilstand i et godt sykehjem (korttidsplass eller fast plass), men som ikke får tilbudet. Vi mangler pålitelig statistikk, men et bestemt inntrykk er at et økende antall pasienter med alvorlig kronisk sykdom 
reinnlegges helt forutsigbart etter å ha vært sendt hjem mot sykehusets råd og deretter blitt funnet forkomne, hjelpeløse og medisinsk ustabile. Lorentzen og medarbeidere fant at flere pasienter ble skrevet ut til korttidsplass etter reinnleggelsen enn etter primærinnleggelsen, hvilket tyder på at også denne kategorien var representert i deres materiale. Vi er havnet $\mathrm{i}$ en paradoksal situasjon: Samhandlingsreformens insentiver og det fallende sengetallet $\mathrm{i}$ sykehus stimulerer til å få pasientene raskt ut av sykehusene, mens kommunenes ofte noe urealistiske og ensidige satsing på hjemmebasert omsorg stadig hyppigere fører til at pasientene dekompenserer og må sendes til sykehus. Sykehuset blir da buffer i de tilfellene der kommunen har undervurdert pasientens helseproblemer. Denne situasjonen er ikke god verken for pasienter eller helsepersonell.

Vi er havnet i en paradoksal situasjon

Internasjonal forskning antyder at andelen av reinnleggelser som vurderes som potensielt forebyggbare, varierer meget sterkt (2), og at instrumenter for å predikere risiko for reinnleggelser for det meste fungerer dårlig (3). Norsk forskning dokumenterer imidlertid effektive tiltak mot reinnleggelser. Helge Garåsen og medarbeidere i Trondheim fant allerede i $2007 \mathrm{i}$ en randomisert studie at forsterkede sykehjemsavdelinger (intermediæravdelinger), som overtar behandlingen sømløst etter at sykehuset har gjort sitt, ga en reduksjon i reinnleggelser fra drøyt $35 \%$ i kontrollgruppen til snaut $20 \%$ blant dem som fikk tilbudet (4). Gro Berntsen og medarbeidere i Tromsø viste nylig at et tverrfaglig geriatrisk team, som var bemannet både fra sykehus og primærhelsetjeneste, og som tok en sterk koordinerende rolle både før og etter utskrivningen av multisyke eldre, førte til drøyt 30 \% reduksjon i risikoen for reinnleggelse (5). Et vesentlig element i begge modeller synes å være en tillitsfull faglig dialog mellom sykehus og primærhelsetjeneste. Tiltakene virker sannsynligvis mot reinnleggelser både i kategori to og kategori tre etter inndelingen over: Sykehusene blir stimulert til å gjøre sin del av jobben ordentlig, inkludert god informasjonsoverføring, og kommunene får rigget seg til å overta stafettpinnen trygt. Dessverre har vi ikke fått noen vesentlig satsing på tiltak skåret over disse lestene. I stedet har vi fått økonomiske straffeordninger med dagmulkter og formelle vedtak som fremmer konflikt fremfor samarbeid rundt utskrivningene (6).

Gjensidig forpliktende og respektfullt samarbeid på tvers av forvaltningsnivåene kan etter alt å dømme forebygge unødvendige reinnleggelser. Når skal vi få en ekte samhandlingsreform?

\section{LITTERATUR:}

1. Lorentzen IC, Larsby K, Bugge E et al. Reinnleggelser ved en hjertemedisinsk avdeling. Tidsskr Nor Legeforen 2020; 140. doi: 10.4045/tidsskr.19.0225. [CrossRef]

2. van Walraven C, Bennett C, Jennings A et al. Proportion of hospital readmissions deemed avoidable: a systematic review. CMAJ 2011; 183: E391-402. [PubMed][CrossRef]

3. Hekkert K, van der Brug F, Borghans I et al. How to identify potentially preventable readmissions by classifying them using a national administrative database. Int J Qual Health Care 2017; 29: 826-32. [PubMed][CrossRef]

4. Garåsen H, Windspoll R, Johnsen R. Intermediate care at a community hospital as an alternative to prolonged general hospital care for elderly patients: a randomised controlled trial. BMC Public Health 2007; 7: 68. [PubMed][CrossRef]

5. Berntsen GKR, Dalbakk M, Hurley JS et al. Person-centred, integrated and pro-active care for multimorbid elderly with advanced care needs: a propensity score-matched controlled trial. BMC Health Serv Res 2019; 19: 682. [PubMed][CrossRef]

6. Wyller TB. Hvem lurte Aud Kvalbein? I: Haukelien H, Wyller TB, red. Ny helsepolitikk. Det finnes løsninger. Oslo: Dreyer, 2017: 83-93. 
Publisert: 13. januar 2020. Tidsskr Nor Legeforen. DOI: 10.4045/tidsskr.19.0724 (c) Tidsskrift for Den norske legeforening 2020. Lastet ned fra tidsskriftet.no 